\title{
A Good Lesson Plan is Half Done
}

\author{
Qingfeng Shen*, Jun Zhang \\ Foreign Language Teaching and Research Section, 7855 Renmin Street, Jilin Province, China \\ *Corresponding author
}

\begin{abstract}
Two overriding principles are supporting good lesson planning. One is variety, the other is flexibility. The first one means involving students in many different types of activity and where possible introducing them to a wide selection of materials. Flexibility refers to a teacher's capability to use any number of different techniques and not to be a slave to one methodology. It is also important when dealing with the plan in the classroom, for many numbers of reasons what the purpose is. In this article, the author analyzes and summarizes the methods of making good lesson plan by the methods of systematic analysis to solve the tricky problems for English teachers in lesson planning.
\end{abstract}

Keywords: Lesson plan, Principles, Components

\section{INTRODUCTION}

Our goal should be that it is to provide different learning activities to help individual students to learn a foreign language. What's more, it has the meaning of giving students a purpose to tell them what it is. All students need to know why they want to do something and what they have achieved in their previous study. This is what teacher believes that diversity must be flexible, because the only way to provide diversity is to use more different technologies from many aspects: not all technologies are applied to methodology. This teacher should immediately suspect anyone who claims to have an answer to language teaching, because that would be a flaw that means flexibility.

\section{VARIETY}

Variety means that students participate in different types of activities and, where possible, introduce a wide range of materials. It also means the way to plan learning, because students always face the same class, which is easy to discourage them. Same type of class they may easily become de-motivated. Only when the teacher thinks that the learning experience is permanently stimulating and interesting can such risks be avoided completely. Of course, this is hard to achieve, but at least when the activities faced by these students are different, they will be interested in it and do things. If there is a new language appeared in these activities that students are facing, it will. New languages are always introduced in the same pattern (for example, in conversation), and then the introductory phase of the course becomes more and more difficult. All reading activities are concentrated on extracting specific information. Students would never ask for anything else. Reading becomes less and less interesting. The same applies to many continuous repetitions of activities. Our goal should be that it is to provide different learning activities to help individual students to learn a foreign language. What's more, it has the meaning of giving students a purpose to tell them what it is and what students need to know why they want to do something and what they are going to achieve.

\section{FLEXIBILITY}

Flexibility refers to the ability of teachers to apply different skills, not to decline. Flexibility is also important when mentioned to discuss the end of the plan from a different perspective in class. End students need to know why they do something and what they achieve flexibility and flexibility for a variety of reasons, which is also important when dealing with plans in class. There, in this case, flexible teachers change their plans. Flexibility is its characteristic, and we will look forward to teachers with real adaptability. Teachers who believe in diversity must be flexible, because the only way to provide diversity is to use many different skills: not all skills are methodology in the same direction. Teachers should at once doubt anyone who claims to have an answer to language teaching, because by this way, it means that there would be a lack of flexibility.

\section{MAJOR COMPONENTS OF LESSON PLAN}

The lesson plans that we will discuss are very much detailed. It should be got understood by us that most of the experienced teachers have no regulations on what to do. The details in our lesson plan before class and model plan are considered extremely necessary for the following two reasons. The first one is that teachers lack of experience need a reference outline to complete the following task plan. The form of the second plan forces those teachers lack of 
experience to consider all aspects of the plan which might be considered desirable.

The plan consists of five main parts: course description, recently finished work, aims, teaching contents and relevant additional contents. If we have talked about it before, we could look at a model plan.

\subsection{Course Description}

The teacher may put this part of the plan in his mind: the more familiar he is with the group, the more he knows about it. That class description should include a description of the students he teaches, an explanation of the time, the frequency and time of the class that he plans to teach, and a review of the normal condition and enrollment. We will see how it works in the sample plan.

\subsection{Recent Finished Work}

Teachers must read the details of students' recent work in mind or on paper to include the activities they take part in, the aim and detailed content of the course, as well as the language communication ways and learning models they have learned. Only when all of these things are got to be known or remembered by him could a teacher make soundly reasonable planning mind for later study.

\subsection{The Aim}

Teacher should have time to write them down or type his goal of the class. He always has much more than one way, because there are many steps in the class, each step is to achieve a certain purpose.

The goal is the goal set by the teacher for the students, and they are related to the goal that the students have done or will achieve. Generally speaking, (for example, to practice for students, to extract some information from the text) and language related information (for example, to let students practice using the past simple time and regular and irregular verbs, questions and answers) written goals are more or less specific, depending on the specific goals of teachers in the field of foreign language teaching.

Therefore, the goal is the teacher's goal. She may be related to activities, language types, or a combination of all of these activities.

\subsection{Teaching Content}

The teaching content is the schedule. Here the teacher described exactly what he would do in the class. It covers the following five points:

(1) Context: The teacher recounted the history of his activities here. Plan. The simulation board can be an activity of a travel agency. The teacher organizes a class to explain their activities.

(2) Classroom activities: The teacher says that if there are pictures on the wall or picture recorders and other languages, it is an unexpected oral communication activity will to introduce the teacher to describe the new language.

(3) Help: Yell can I make a suggestion? Which delete wants a language?

(4) Language: The teacher said that Langer would introduce a new language and some or all of the model designers. The activity is an unpredictable oral communication activity. Shouting, shouting can give me a suggestion example: which one wants tongue?

(5) Possible problems: Number of activities A. Teacher often predicts that new expression languages will have problem languages due to different languages. Formula simulation of a precedent may cause problems because there are many different terms don't worry, etc. Teachers have to be aware of these potential thoughts. Think of the soldier's activities as complex to organize actions for you. The teacher must be aware of this and know how to overcome it.

\section{A SPECIMEN LESSON PLAN}

Let's start a sample class now. This is the sample we have learned and this is for young people adult.

\subsection{Description of the Class}

There are 30 students in one class with 21 boys and 9 girls. The class duration is from 8 to 10 a.m. on Monday. Enthusiastic, but often tired you, they college students studied for about 40 hours English recent graduate students work on the following topics:

\subsection{Recent Finished Work}

To be organizational model (different from the rest of the world):

(1) invitation to dialogue and free practice

(2) sentence pattern "there is", "there are" with maps, etc.

(3) simplicity + frequency of demonstration / practice

(4) monitoring exercise

(5) some games use frequency verbs as listening indexes

(6) students follow footnote

(7) several games using frequency adverbs to study

(8) with direction, to do listening exercises

\subsection{Objective}

(1) to allow students to learn to read to obtain specific information.

(2) let students do realistic writing exercises

(3) maintaining relative verbs 
(4) to express agreement and disagreement.

(5) Allow students to relax and have real oral communication in all languages.

\subsection{Content}

(1) Goal:

A. And Holidays and / or cruises, activities

B. Class organization: students write sentences, preferences

C. The professor showed agreement and disagreement.

D. The activity started from a fixed stage: students work together.

E. There is no other language except for the form: students need paper and pens.

(2) Language: (Expected time: 10 minutes)

A. The professor will not correct these mistakes (unless they are serious) and will correct them.

B. Classroom activities and organization: students read the text and answer eight questions yes / no.

C. Reading actions.

D. The reading part is a textbook.

E. Students' difficulties in language differences. College students make a lot of mistakes in school.

F. To instruct students clearly.

\subsection{Additional Possibilities}

Several points can be made about this curriculum. First of all, decisions were taken relating to what the pupils had recently done (more recent finished work). It seemed that the students did not read much as required and that a lot of their oral work was either in good practicing way or best controlled practice output as it was imagined. There were not many ways to express yourself as you thought of yourselves and these listening had already been done by them as input to prepare the way for teaching students how to ask for and give directions. The first activity in the plan aims to answer the need for self-expression while at the same time giving students a simple way of agreeing and disagreeing. It also serves as a general lead-in to the topic of the reading text.

The reading passage comes from the textbook the students are using and the follow-up task serves the dual purpose not only of giving students a realistic task within their reach but also of recycling language that they have recently been studying. The "describe and draw" activity has the dual advantage of giving students genuinely communicative language use while at the same time being enjoyable and intentional since by that stage students may well feel the need for a more enjoyable activity.

\section{CONCLUSION}

We have considered the importance of making a lesson plan and have stressed the need to think of the activities that would be suitable or our class pointing out the need for the things as variety, flexibility and something like balance. We have also talked much about the major components of a lesson plan. Besides, we have looked at a detailed specimen lesson plan, stressing that experienced teachers probably do not write planning such great details, however, so hat, to do this is just like to be forced by the teacher to consider important aspects of planning a lesson.

\section{REFERENCES}

[1] Bussmann H., 2000. Routledge Dictionary of Language and Linguistics. Foreign Language Teaching and Research Press.

[2] Johns T., Davies F., 2003. Text as a vehicle for information: the classroom use of written texts in teaching reading in a foreign language, Reading in a Foreign Language, 1 (1), pp. 1-19.

[3] Pegolo C., 2015. More Efficient Silent Reading Comprehension. Reading in a Foreign Language 3/1.

[4] Rivers M. W., 2008. Teaching Foreign Language Skills. Oxford: Oxford University Press.

[5] Rivers M. W. \& Temperley M. S. 1978. A Practical Guide to the Teaching of English as a Second or Foreign Language. Oxford: Oxford University Press.

[6] Williams, R. C., R. Ray, \& J. M. Swales. 2004. Communication in English for Technical Students. Hyderabad: Orient Longman. 